\title{
Sakallı kızılağaç (Alnus glutinosa subsp. barbata) meşceresinin doğal yolla gençleştirilmesi (Harşit Orman İşletme Şefliği örneği)
}

\author{
Natural regeneration of Black Alder (Alnus glutinosa subsp. barbata) stands (An example of Harşit Forestry Enterprise)
}

\author{
Nihan YILDIRIM ${ }^{1}$ id ibrahim TURNA ${ }^{2}$ (D) Nebahat YILDIRIM² \\ ${ }^{1}$ Giresun Orman Bölge Müdürlüğü, Silvikültür Şube Müdürlüğü, Giresun \\ ${ }^{2}$ Karadeniz Teknik Üniversitesi, Orman Fakültesi, Orman Mühendisliği Bölümü, Trabzon
}

Eser Bilgisi / Article Info

Araştırma makalesi / Research article

DOI: 10.17474/artvinofd.690646

Sorumlu yazar / Corresponding author Nebahat YILDIRIM

e-mail: nebahat.yildirim@ktu.edu.tr

Geliş tarihi / Received

18.02.2020

Düzeltme tarihi / Received in revised form

09.03.2020

Kabul Tarihi / Accepted

17.03.2020

Elektronik erișim / Online available

02.05.2020

\section{Anahtar kelimeler:}

Alnus glutinosa subsp. barbata

Doğal gençleştirme

Diri örtü temizliği

Harşit

\section{Keywords:}

Alnus glutinosa subsp. barbata

Natural regeneration

Land clearing

Harşit

\begin{abstract}
Özet
Doğada her canlının olduğu gibi ormanların da sürekli var olması, yaşlanan ya da değişik nedenlerle zarar görüp ölen bireylerin yerini yeni genç bireylerin almasıyla mümkün olacaktır. Bu nedenle ormanlarımızda uygulanan gençleştirme çalışmaları ve bu çalışmaların başarısı büyük önem taşımaktadır. Çalışma kapsamında, Harşit Orman İşletme Şefliğine ait Sakallı kızılağaç (Alnus glutinosa subsp. barbata) meşceresinin doğal gençleştirme yöntemlerinden biri olan büyük alan siper vaziyeti ile gençleştirilmesi ve gençlik bakımlarından diri örtü temizliğinin gençliğin gelişimi üzerine etkisinin ortaya konulması amaçlanmıştır. Gençleştirme çalışmasına 2012 yılında arazi hazırlı̆ı ile başlanılmış ve 2016 Kasım-Aralık ayında ise boşaltma kesimi ile sahadan çıkılmıştır. illk çimlenmeler 2013 yılı Nisan ayında gözlemlenmiştir. Gençleştirme alanında üç farklı şiddette diri örtü temizliği yapılmış ve uygulanan diri örtü temizlik derecelerinin gençlik sayısı ve boy gelişimi açısından etkileri belirlenmiştir. Çalışma sonucunda; 2013-2015 yılları arasında yapılan ölçüm ve sayımlarla gençlik boyları ve sayıları ortaya konulmuştur. Bir yaşındaki gençliklerin boylarında yapılan ölçümlerde tüm işlemlere ait ortalama boy $5.92 \mathrm{~cm}$, iki yaşında $39.23 \mathrm{~cm}$ ve üç yaşında ise $65.46 \mathrm{~cm}$ 'dir. Diri örtü temizliği işlemleri bakımından bir yaşındaki ve üç yaşındaki gençlik boyları arasında istatistiksel olarak anlamlı $(P<0.05)$ farklılıklar olduğu belirlenmiştir.
\end{abstract}

\begin{abstract}
The existence of forests as well as every living thing in nature will be possible by the replacement the young individuals to the position of aged or dead individuals who have been damaged due to various reasons. For this reason, the regeneration methods implemented in forests and the success of these studies are of great importance. In this study, it was aimed to regeneration with compartment shelterwood system, one of the natural regeneration methods, of Alnus glutinosa subsp. barbata stand in Harşit Forestry Enterprise, and the determination of effects on juvenility development of land clearing from regeneration tending. In 2012, regeneration efforts were started with land preparation and final cutting was made in November-December 2016. The first germination was observed in April 2013. In regeneration area, three different land clearing treatments were carried out and tried to determine their effects on the number and length of juvenility. As a result of the study; the number of juvenility and juvenility length were determined by the making measurement and counting between the years of 2013-2015. In the measurements made in one year-old juvenility, the average juvenility length of all treatments was $5.92 \mathrm{~cm}$, this was obtained as $39.23 \mathrm{~cm}$ for two-year-old juvenility, and $65.46 \mathrm{~cm}$ for three-year-old juvenility. In addition, it was determined that there are statistically significant differences $(P<0.05)$ between juvenility length values of one and three-year-old juvenilities in terms of land clearing interventions.
\end{abstract}

\section{GiRiş}

Doğal kaynaklarımızın en iyi şekilde işletilmesi, ülke ve yöre halkının optimum faydalanmasına sunulması zorunludur. Bu kaynakların başında mevcut ormanlar ve bunları oluşturan bitki türlerinin çok amaçlı kullanımı dikkate alınarak, maksimum yarar sağlayacak şekilde işletilmesi gerekir. Çok amaçı yararlanacağımız ağaç türlerinden birisi de kızılağaçlardır.
Kızılağaçlar, Fagales takımının Betulaceae familyasının Alnus cinsine ait olup, Türkiye'de Doğu Kızılağacı (Alnus orientalis Decne.) ve Adi Kızılağaç (Alnus glutinosa (L.) Gaertn.) olmak üzere iki türü bulunmaktadır. Bu türlere bağlı altı adet takson bulunmaktadır. Bunlar; Alnus orientalis Decne. var. orientalis, Alnus orientalis Decne. var. pubescens Dippel (Endemik), Alnus glutinosa (L.) Gaertn. subsp. glutinosa, Alnus glutinosa (L.) Gaertn. 
subsp. barbata (C.A Mey.) Yalt., Alnus glutinosa (L.) Gaertn. subsp. antitaurica Yalt. (Endemik) ve Alnus glutinosa (L.) Gaertn. subsp. betuloides Anşin (Endemik) türleridir (Anşin ve Özkan 2006, Güner ve ark. 2012, Anonim 2015).

Alnus glutinosa subsp. barbata, fitocoğrafik olarak Karadeniz elementi olup Doğu Karadeniz Bölgesi'nde yayılış göstermektedir (Güner ve ark. 2012). Sakallı Kızılağaç, Doğu Karadeniz Bölgesinde doğu ladini, Doğu Karadeniz göknarı, sarıçam ve doğu kayını türlerinden sonra yayılış bakımından önemli bir yer tutmaktadır. Ordu, Giresun, Gümüşhane, Trabzon, Rize, Artvin illerinde yapraklı ormanlar ile saf ladin ormanlarında, rutubetli yamaçlar, vadi tabanları ve dere kenarlarında yetişmektedir. Deniz seviyesinden başlayarak $1700 \mathrm{~m}$ yüksekliklere kadar çıkabilmektedir (Odabaşı ve ark. 2004, Mamıkoğlu 2015). Genellikle yarı ışık ağacı niteliğinde olup optimum yetişme ortamlarında ışık isteği azalır. Biyolojisine uygun yetişme ortamlarında (taban suyu yüksek, gevşek balçıklı topraklar) dolgun ve düzgün gövdeler yapabilen ve $30 \mathrm{~m}$ boya ulaşabilen birinci sınıf orman ağacıdır (Aksoy 1986, Carus 1994). Kızılağaç toprak isteği bakımından kanaatkâr bir tür olup, orta derecede asidik topraklarda da iyi yetişebilir. Kanaatkâr olmasının esası köklerinin azot bağlayıcı özelliğini taşımasından kaynaklanmaktadır (Wheeler 1986, Ürgenç 1992).

Kızılağacın hızlı gelişmesi, zararlılara karşı dayanıklılığı ve kısa üretim periyodunda birim alanda sağladığı odun verimi ve artımı diğer ağaç türlerine göre yüksektir. Bu sebeple, kızılağaç özel olarak ele alınması gereken bir türdür (Batu ve Kapucu 1995, Ayan ve ark. 1998). Büyüme performansı ilk 10 yılda çok hızı iken sonradan yavaşlayan kızılağacın daha kısa sürelerle işletilmesi ekonomik anlamda kârlılığı artırabilecektir (Akyüz 1998). Kontrplak üretiminde kızılağacın kullanımı amaçlı yapılan çalışmada tomruk çaplarının en az $35 \mathrm{~cm}$ olması gerektiği, Türkiye ve Avrupa'da bu amaçla kullanılan ağaç türlerinden biri olan kayının bu çapa ulaşması için geçen süre 120 yıl iken kızılağaçlar için bu süre 60 yıldır (Güdül ve ark. 2019). Orta Avrupa'da mobilya sektöründe tropik odunlara alternatif olarak değerlendirilmeye başlanmıştır (Huss ve Kahveci 2009). Kızılağaç aynı zamanda sel kontrolünde, dere ve nehir yataklarının stabilizasyonunda, özellikle de nehir ekosistemlerinin ıslah çalışmalarında önemli bir yere sahiptir. Özellikle Doğu Karadeniz Bölgesinde doğal ormanların üzerindeki sosyal baskının ve tahribatın önlenmesinde kızılağaç ormanları en önemli seçeneklerden biri olarak karşımıza çıkmaktadır (Ayan ve ark. 1998). Doğal yayılış alanlarında kızılağaç ormanlarının devamlılığının sağlanması ve sürdürülebilir olarak işletilmesi için gerek bozuk gerekse idare süresini doldurmuş alanların gençleştirilmesi önem arz etmektedir.

Ormancılıkta gençleştirme, süreklilik prensibinin esas alındığı düzenli bir orman işletmeciliği olup kararlaştırılan idare süresini doldurmuş ya da strüktürü (tabakalılık, kapalılık ve sıklık) ve tekstürü (karışım şekli, oranı vb.) bozulmuş meşcerelerde yetişme ortamı koşullarına bağı olarak yeni jenerasyonun getirilmesi işlemidir. Saatçioğlu (1979) ve Odabaşı ve ark. (2004), kızılağaçların biyolojisi göz önüne alındığında, en iyi doğal gençleştirme yönteminin siper vaziyetiyle gençleştirme olduğunu belirtmektedir. Gençleştirme, meşcere büyüklüğüne ve karışım durumuna göre gruplarda yapılacağı gibi büyük alanlarda da yapılabilir. Böylece grup siper ya da büyük alan siper vaziyeti ile gençleştirilebilir. Biyolojik çeşitliliğin yerinde korunmasını sağlayan in-situ önlemlerinden en ucuzu doğal gençleştirmedir. Doğal gençleştirmeyle elde edilmiş meşcerelerin, ekim veya dikimle kurulmuş meşcerelere göre üstün verim güçlerini dikkate alarak gençleştirme çalışmalarında önceliğimiz, mümkün olan her yerde doğal gençleştirme olmalıdır (Genç 2013).

Gençleştirmeden sonra ilk akla gelen silvikültürel işlem ise gelen gençliğin korunması ve diğer bakım işlemleri ile gelişiminin garanti altına alınmasıdır. Yeni jenerasyon doğal olarak alana gelmişse gençlik, yapay olarak getirilmişse kültür bakımlarına konu edilmektedir. Bakım çalışmaları biyolojik ve ekonomik yönü olan faaliyetlerdir. Gençlik ve sıklık çalışmalarından elde edilen ürün genellikle herhangi bir ticari değer taşımaz. Bu nedenle, gençlik bakımları ekonomik getirisi olmadığından ihmal edilen çalışmalardır. Bununla birlikte bakım müdahaleleri, meşçere de yarattığı gelişme seyri ile daha sonraki çağlarda ekonomik değerlerle ortaya çıkabilmektedir (Edwards 1980). Bilindiği gibi, gençlik bakımı belli bir süre için söz konusudur. Bu süre içinde, gençliklerin gelişerek 
rakiplerine üstünlük sağlamaları, onlara yenik düşmeden, bir arada yaşamını sürdürmeleri gerekir. Gençlik bakımı yapılmayan alanlarda otsu bitkiler ve çalılar gençliğin normal büyümesini engellemekte, artım kayıplarına neden olmakta, yer yer de gençliği boğarak öldürmektedir (Eler ve ark. 1992, Genç 2013). Özellikle Doğu Karadeniz bölgesi diri örtü bakımından yoğun bir bölge olduğundan gençlikte yapılacak olan diri örtü temizliği kaçınıımazdır. Zira kızılağacın doğal yayılış alanlarında yoğun olarak böğürtlen ve eğrelti başta olmak üzere orman gülleri, diken ucu, ayı üzümleri vb. türler sorun teşkil etmektedir (Ata 1995).

Bu bağlamda çalışmanın amacı; Harşit Orman İşletme Şefliği sınırları içerisinde bulunan Sakallı Kızılağaç meşceresinde doğal gençleştirme yöntemlerinden büyük alan siper metodu ile gençleştirilmesi ve gençlik bakımlarından diri örtü temizliğinin (boğma tehlikesinin önlenmesi) gençliğin gelişimi üzerine etkisinin ortaya konulması olmuştur.

\section{MATERYAL VE YÖNTEM}

\section{Materyal}

Bu çalışma, Tirebolu Orman İşletme Müdürlüğü'ne bağlı Harşit Orman İşletme Şefliği sınırları içerisinde bulunan, Sakallı Kızılağaç meşceresinde gerçekleştirilmiştir. Çalışma alanı ortalama 1010 m yükseltide, kuzey doğu bakıda ve ortalama \% 60 eğimde yer almaktadır. Saha II. bonitette, meşcere yaşı ortalama 70 olup alanda gençlik bulunmamaktadır. Çalışmanın başladığı 2012 yılında yürürlükte olan amenajman planına göre meşcere tipi bozuk kızılağaç (BKz) olup alanı 11.4 ha'dır. Ancak, aktüel durum itibariyle alan üzerinde yapılan örneklemede kapalılığın 0.3-0.4 olduğu, bozuk yapıda olmadığı belirlenmiştir. Nitekim ilgili Orman İşletme Şefliği de bu saha gibi benzer yapıdaki sahaları doğal gençleştirmeye konu etmektedir. Çalışmaya konu Sakallı Kızılağaç meşceresinin meşcere haritasındaki yeri ve konumu Şekil 1 'de gösterilmiştir.

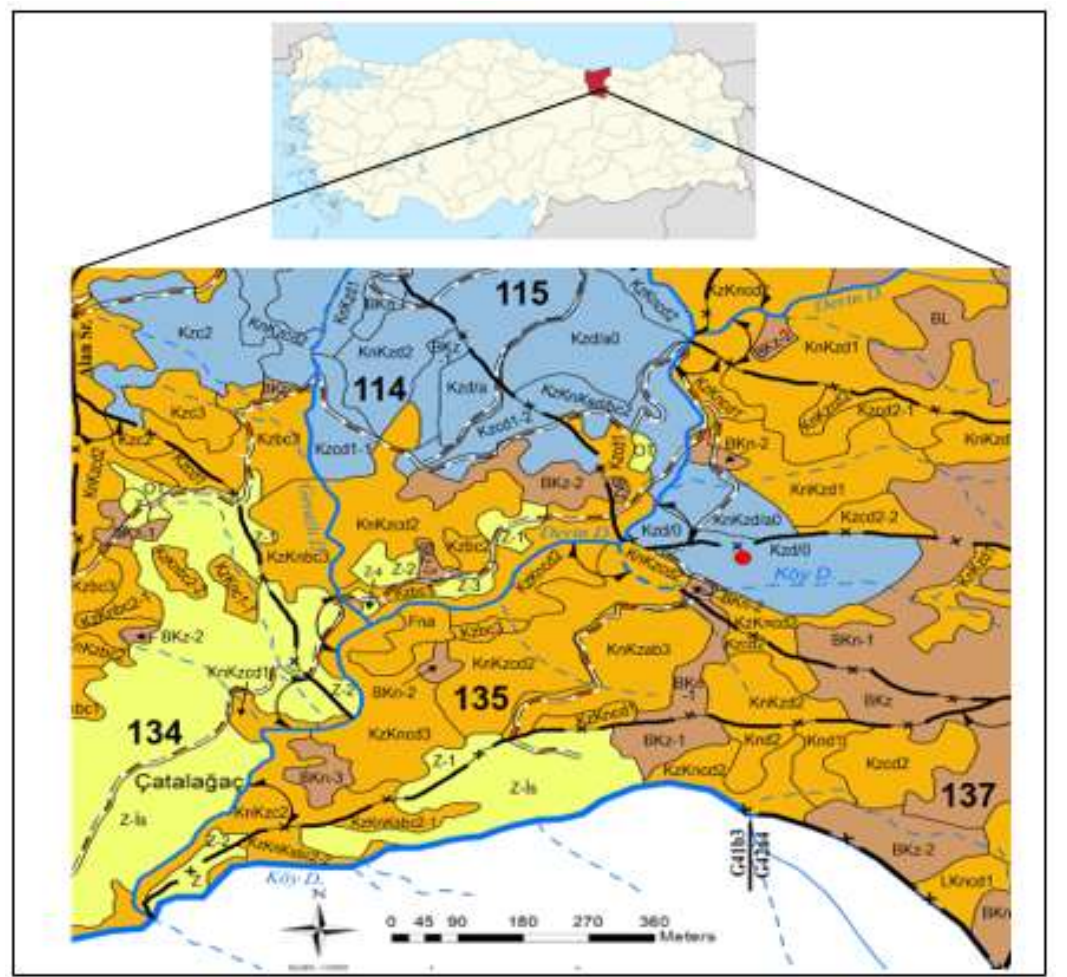

Şekil 1. Araştırma alanının Türkiye haritasındaki konumu ve meşcere haritasındaki yeri

Giresun-Harşit deneme alanına ait alınan meteoroloji verilerine (2013-2015) göre ortalama sıcaklık değerleri $14.9^{\circ} \mathrm{C}$ ve ortalama nispi nem $\% 68.5$ ile $\% 73.9$ arasında olduğu belirlenmiştir. 


\section{Yöntem}

Çalışma alanı dikenli tel çit ile çevrilerek kontrol altına alınmış, alanın eğimi eğimölçer ile yükseltisi ise GPS ile belirlenmiş olup 2012 yılı Eylül ayında büyük alan siper vaziyetiyle ile gençleştirmeye konu edilmiştir. Yetişme ortamı özelliklerini belirlemek amacıyla alanı temsil edecek şekilde bir adet toprak profili alınmış ve analizi yapılmıştır. Araştırma alanına ait ölçüm yapılan 20132015 yılları arasındaki iklim verileri (minimum, maksimum ve ortalama sıcaklık, nispi nem ve toplam yağış) en yakın meteoroloji istasyonundan elde edilmiştir.

Çalışma alanındaki meşcere gevşek kapalı olduğundan, mevut ağaçların homojen dağılım göstermesinden dolayı hazırlık kesimine (HK) gerek duyulmamış ve gençleştirme çalışmalarına tohumlama kesimi (TK) ile başlanılmıştır. Kesimler, 2012 yılında diri örtü temizliği ve toprak işleme çalışmaları tohum dökümünden önce mini ekskavatörle tamamlanmıştır. Kökleme yapılarak toprakla bağlantısı kesilen diri örtü 3.0-3.5 m mesafelerle 1.0-1.5 m'lik şeritler halinde yığılmıştır. Ardından toprak şeritler halinde işlenmiştir. TK ile kapalılık 0.3-0.4'den 0.1-0.2 seviyelerine indirilmiştir. Tohum ağacı olarak bırakılan fertlerin elit bireyler olmasına, sahaya homojen olarak dağılmalarına ve eşit siper etkisi oluşturmalarına özen gösterilmiştir. 2016 yılı Kasım-Aralık ayında kızılağaç gençlikleri biyolojik bağımsızlıklarını kazandığından boşaltma kesimi (BK) yapılmıştır. Boşaltma kesimi sonrası çimlenme başarısının tespiti ve diri örtünün gelen gençliğin gelişimine etkisinin belirlenmesi olmak üzere iki farklı aşamada gerçekleştirilmiştir.

Gençleştirme alanında çimlenme başarısı tespitine yönelik olarak hazırlanan $1 \times 1 \mathrm{~m}^{\prime}$ lik tahta çıtalarla üç sayım parseli tesis edilmiş ve sayımlar üç yıl boyunca sabitlenen bu üç parsellerde gerçekleştirilmiştir. Ölçüme konu parsellerden bir adedi (1.parsel) tohum ağaçlarının siper etkisi oluşturduğu bir noktaya, bir adedi (2.parsel) ağaç tepe taç alanı dışında kalan açık bir alana, bir adedi (3.parsel) de çimlenmelerle birlikte diri örtünün yoğun olarak gelmeye başladığı bir noktaya olmak üzere toplamda üç adet sayım parseli oluşturulmuştur. Gençleştirmeye konu sahada 2013 yılı vejetasyon dönemi başında (Nisan) yapılan incelemelerde çimlenmelerin başladığı gözlenmiştir. Bu nedenle ilk gençleştirme başarısı tespitleri 2013 yılı vejetasyon dönemi sonunda (Eylül) yine aynı noktalarda gerçekleştirilmiştir.

Diri örtü yoğunluğunun gençlik sayısı ve boyu üzerindeki etkisini belirlemek amacıyla; 2013 yılı Haziran ayında 10x10 m (100 m²) ebatlarında 3 farklı işlem ve bu işlemlerin 3 'er tekrar olmak üzere toplam 9 parsel rastlantı blokları deneme desenine göre tesis edilmiştir. Buna göre; diri örtü temizliği yapılmamış kontrol (1. işlem), diri örtünün \%50'si uzaklaştırılmış (2. işlem) ve diri örtünün tamamı uzaklaştııılmış (3. işlem) olmak üzere üç farklı işlem uygulanmıştır. Diri örtü baskısının tespiti için seçilen alanlarda gençliklerin homojen dağııışta olmasına dikkat edilmiştir. Diri örtü temizliği iş gücü ile yapılmış olup çalışma sırasında orak ve tahra kullanıımıştır. Tesis edilen 9 adet parselin her birinde $1 \times 1 \mathrm{~m}^{\prime}$ lik alanlarda 2013, 2014 ve 2015 yıllarında gençlik sayımları ve boy ölçümleri cetvel ve şerit metre yardımıyla $\mathrm{cm}$ hassasiyetinde gerçekleştirilmiştir. Böylece ilk gelen gençliklerin yıllara bağlı olarak yaşama yüzdeleri belirlenmeye çalışımıştır.

Elde edilen veriler SPSS 20.0 istatistik paket programı yardımıyla değerlendirilmiştir. Diri örtü yoğunluğuna bağlı olarak gençlik sayısı ve boy değerleri arasındaki farkların anlamlılığı varyans analizi ile tespit edilmiştir. Duncan ve Bonferroni testi kullanılarak gruplandırmalar ve ikili karşılaştırma sonuçları ortaya koyulmuştur.

\section{BULGULAR VE TARTIŞMA}

\section{Gençleştirme başarısına ilişkin bulgular ve tartışma}

Yapılan gençleştirme çalışması ile TK sırasında 63 adet/ ha ağaç damgalanmış, $33.79 \mathrm{~m}^{3} /$ ha eta alınmıştır. TK'nin ardından toplamda 80 adet/ha tohum ağacı bırakılmıştır. Çalışma alanında TK kapalılık 0.1-0.2'ye indirildiğinden ışık kesimine (IK)'ne ihtiyaç duyulmamıştır. 2016 yılında gençlik 50-70 cm boya erişip biyolojik bağımsızlığına kavuştuğunda, değer ağacı bırakılmaksızın BK ile boşaltılmıştır. BK sırasında alanda 9 adet/ha ağaç damgalanmış ve $5.820 \mathrm{~m}^{3} /$ ha eta alınmıştır.

Gençlik sayımlarına göre, 2013 yılında yapılan sayımlarda; 1.parselde 17 adet $/ \mathrm{m}^{2}$, 2. parselde 22 adet $/ \mathrm{m}^{2}$ ve 3 . parselde 19 adet $/ \mathrm{m}^{2}$ çimlenmeler belirlenmiştir. 
Sabitleştirilmiş aynı parsellerde yapılan sayımlarda, 2014 yılı Eylül ayında 1. parselde 14 adet $/ \mathrm{m}^{2}$, 2. parselde 20 adet $/ \mathrm{m}^{2}$ ve 3. parselde 18 adet $/ \mathrm{m}^{2}$ gençlik tespit edilmiştir. 2015 yılı Eylül ayında ise 1. parselde 12 adet $/ \mathrm{m}^{2}$, 2. parselde 16 adet $/ \mathrm{m}^{2}$ ve 3. parselde 9 adet $/ \mathrm{m}^{2}$ gençlik olduğu belirlenmiştir. ilk yıldaki çimlenme ve devam eden iki yıldaki gençlik sayımlarının yıllara bağlı olarak ortalama değerleri Şekil 2'de verilmiştir.

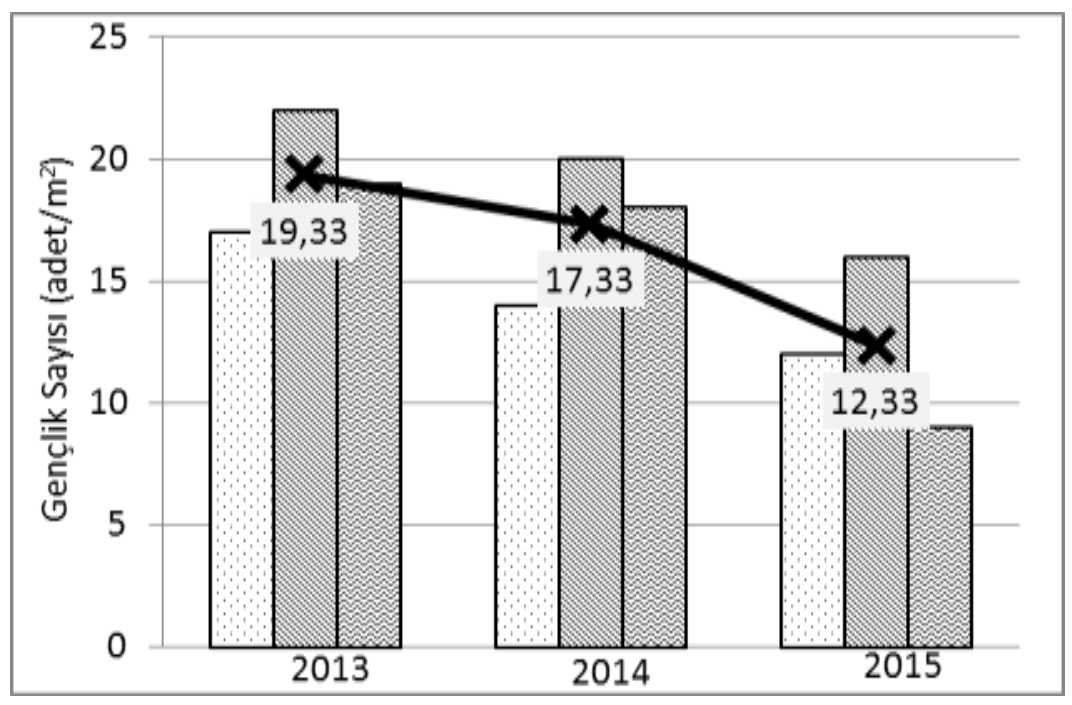

Şekil 2. Yıllara ait parsellerdeki gençlik sayıları ve ortalama sayıları

Yapılan doğal gençleştirme sonucunda çimlenme ve gençlik başarısına ait hektardaki gençlik sayımlarına bakıldığında 2013 yılında ortalama 193300 adet/ha, 2014 yılında 173300 adet/ha ve 2015 yılında ise 123300 adet/ha gençlik sayılmıştır. Gençlik sayısı bakımından 2013 yılından 2014 yılına göre \%10.4 lük bir azalma olurken, 2013-2015 yılında bu oran \% 36.2'lik bir azalma olduğu ortaya çıkmıştır.

Odabaşı ve ark. (2004), yapmış oldukları çalışmada kızılağacın biyolojisi göz önüne alındığında en iyi doğal gençleştirme yönteminin siper altında gençleştirme olduğunu vurgulamışlardır. Başka bir çalışmada, 2012 yılında doğal gençleştirme alanında sırasıyla 0.7, 0.5, 0.3 ve 0.0 kapalılıkta 5550 adet/ha, 5700 adet/ha, 7025 adet/ha ve 12675 adet/ha gençlik sayıları elde edilmiştir. 2013 yilında ise $0.7,0.5,0.3$ ve 0.0 , kapalılık derecelerinde gençlik sayıları sırasıyla 12450 adet/ha, 16975 adet/ha, 12825 adet/ha ve 12900 adet/ha olurken yapay gençleştirmede 2012 ve 2013 yıllarındaki gençlik sayıları, 575 adet/ha ve 500 adet/ha olarak belirlenmiştir (Çatalçam 2014). Benzer şekilde; Kaya (2014), yapmış olduğu çalışmada 2012 yılında doğal gençleştirme sahalarında 0.5-0.7 kapalılık derecelerinde 4525 adet/ha, 0.3-0.5 kapalılıkta 11675 adet/ha gençlik elde ederken yapay gençleştirme sahalarında 1050 adet/ha gençlik elde etmiştir. Böylelikle; doğal gençleştirmenin gençlik sayısı ve başarısı bakımından yapay gençleştirmeye göre tercih edilmesi gerekliliği bu çalışmalarda vurgulanmaktadır.

Ata 1995 'e göre bol bir gençlik elde edilince TK'den 2-3 yıl sonra BK'ne geçilebileceğini belirtmiş olup bu çalışmada da benzer şekilde TK sonrasında başarılı bir gençlik elde edilerek 4 yıl sonra alanda boşaltma kesimi yapıımıştır.

Araştırma alanının toprak yapısını belirlemek amacıyla açılan toprak profilinde alınan toprak örneklerine ait toprak analizlerinde; üst toprağın $(0-30 \mathrm{~cm})$ kumlu balçık, alt toprakların $(30-60,60-90,90-120 \mathrm{~cm})$ ise kumlu killi balçık toprak türünde olduğu tespit edilmiştir. Toprak pH'sı 5.1 ile 5.4 arasında değişmekte olup kuvvetli asit karakterdedir. Bunun yanında üst toprağa ait organik madde içeriği 0.5 ile 2.4 arasında değişmekle birlikte, toprak humusça fakir niteliktedir. Elektriksel iletkenlik (EC) (0.4-0.7) yönünden toprak tuzsuz karakterdedir ve kireç yoktur. Yılmaz (1996), Artvin-Rize yöresi kızılağaç meşceresinde yaptıkları çalışmada toprak yapısı bakımından $\% 58$ 'inin kumlu balçık, \%26,3'ünün balçıklı kum olduğunu ifade etmektedir. Aynı çalışmada toprak pH'sının ise 3.7-7.6 arasında değişmekle birlikte ortalama 
5.6 olarak bulmuşlardır. Kızılağaç meşcerelerinde bazı odun özellikleriyle yetişme ortamı özelliklerinin araştırılmasına yönelik çalışmada, Giresun-Erimez yöresinde toprak türünün $\% 54$ 'ü balçıklı kum, $\% 46$ 'nın kumlu balçık, Trabzon-Maçka yöresi için ise $\% 90$ kumlu balçık, \%10 balçıklı kum olduğunu, yine aynı çalışmada $\mathrm{pH}$ değerlerinin de Maçka için 5.6, Giresun-Erimez için 4.8 olarak tespit edilmiştir (Öztürk 2015).

Doğal gençleştirmenin temel unsurlardan biri de toprak işlemedir. Toprak işleme ile mineral toprak açığa çıkacağından dolayı tohumun çimlenmesi kolaylaşacaktır (Saatçioğlu 1946, Pamay 1966). Bu çalışmada da alanda yoğun mor çiçekli orman gülü (Rhododendron ponticum L.), eğrelti (Pteridium sp.) ve böğürtlen (Rubus sp.) olduğundan arazi hazırlığı (diri örtü temizliği) yapılmış sonrasında toprak işlenmiş olup, bu da gençleştirme başarısında önemli bir etken oluşturmuştur.

\section{Diri örtü temizliğinin gençlik sayısı ve boyuna etkisine ilişkin bulgular ve tartışma}

Tohumdan gelen gençliğin sağlıklı, başarılı ve daha iyi gelişen bir gençlik oluşturması için gençleştirme alanında diri örtüyle mücadele edilmiştir. Üç farklı yoğunluktaki diri örtü temizliği işlemlerine ilişkin 2013, 2014 ve 2015 yıllarında gençlik sayımları gerçekleştirilmiştir. Gençlik sayımlarının işlemlere bağı olarak anlamlı farklılık gösterip göstermediği varyans analizi tespit edilmiş olup, işlem ve yıllar itibariyle elde edilen sonuçlar Şekil 3'de verilmiştir.

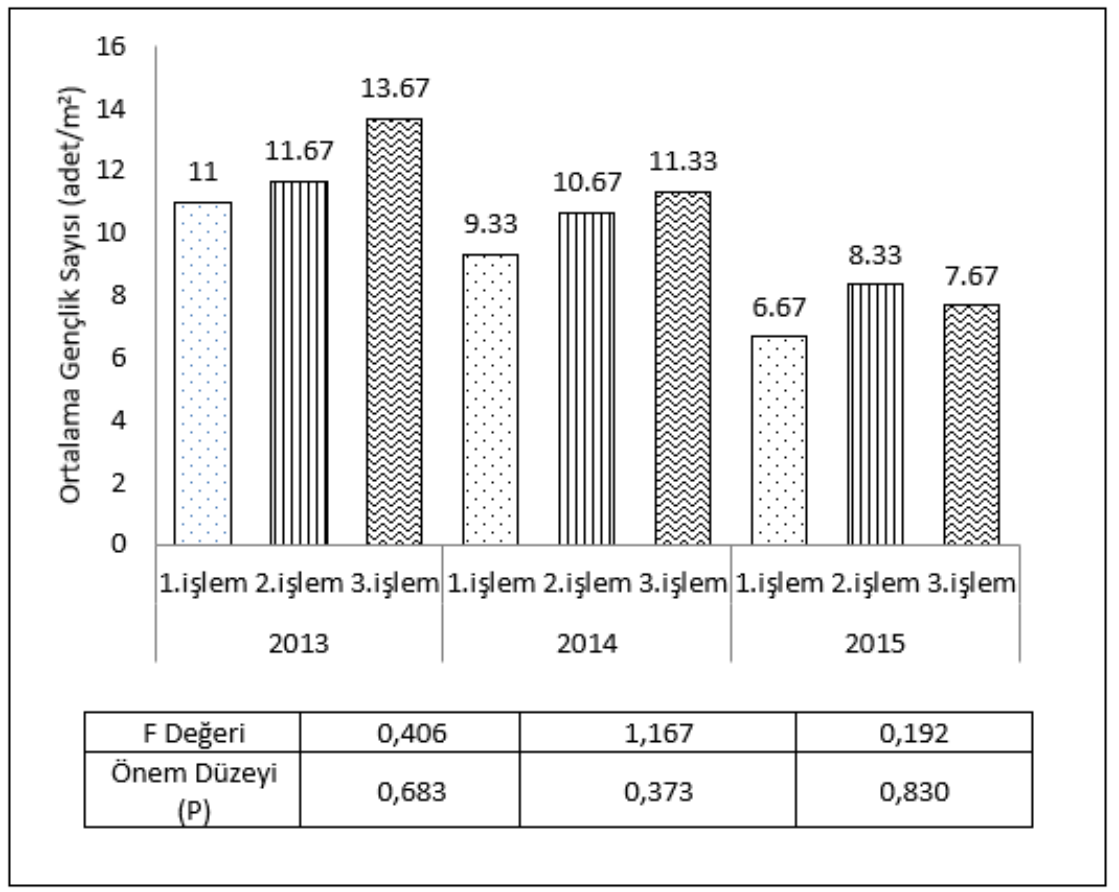

Şekil 3. Yapılan müdahalelere göre üç yıl içindeki ortalama gençlik sayım değerleri ve varyans sonucu

Gençleştirme sahasında diri örtü temizliğinin yapılmadığı (1. işlem) alanda bir yıllık büyüme periyodu sonunda ortalama 11 adet gençlik, 2. işlem (diri örtünün \%50'si uzaklaştırıldı) de ortalama 11.67 adet ve 3 işlem (diri örtünün tamamı uzaklaştırılı) de ise ortalama 13.67 adet elde edilmiştir. İkinci yılsonunda ise 1 işlemde; ortalama 9.33, 2 işlemde; 10.67 ve 3 işlemde ise; 11.33 adet gençlik elde edilmiştir. Üçüncü yılsonunda ise; 1 işlemde; ortalama $6.67,2$ işlemde; 8.33 ve 3 işlemde ise; 7.67 adet gençlik elde edilmiştir (Şekil 3). Yıllara bağlı olarak 2013, 2014 ve 2015 yıllarındaki ortalama olarak gençlik sayımları sırasıyla; 121133 adet/ha, 104433 adet/ha ve 75566 adet/ha olarak belirlenmiştir. Varyans analizi sonucunda üç yıllık periyodda yapılan diri örtü temizliğine bağlı olarak gençlik sayımları arasında istatiksel olarak anlamlı bir farklılık olmamıştır. 
Sakallı Kızılağaç gençleştirme alanında gençlik bakımlarında uygulanan farklı işlemler sonrasında 1 yaşındaki (2013 yılı), 2 yaşındaki (2014 yılı) ve 3 yaşındaki (2015 yılı) gençliğin boy değerleri ve diri örtü temizliğine bağlı olarak gençlik boyları arasında istatistiksel olarak anlamlı farklılıkların olup olmadığını varyans analizi ile tespit edilmiştir (Çizelge 1)

Çizelge 1. Diri örtü temizliğinin gençliğin boyuna etkisine ilişkin varyans analizi sonuçları

\begin{tabular}{|c|c|c|c|c|c|c|c|c|}
\hline \multirow[t]{2}{*}{ Gençliğin Yaşı } & İşlemler & $\begin{array}{c}\text { Ortalama Gençlik } \\
\text { Boyu }(\mathrm{cm})\end{array}$ & $\begin{array}{l}\text { Standart } \\
\text { Sapma }\end{array}$ & Standart Hata & Min. & Mak. & F Değeri & Önem Düzeyi (P) \\
\hline & 1 & 3.91 & 1.97 & 0.34 & 1.5 & 8.0 & \multirow{4}{*}{29.49} & \multirow{4}{*}{$0.000^{*}$} \\
\hline \multirow[t]{2}{*}{1} & 2 & 4.44 & 2.13 & 0.36 & 1.0 & 9.0 & & \\
\hline & 3 & 8.77 & 4.15 & 0.65 & 2.0 & 19.0 & & \\
\hline \multicolumn{2}{|c|}{ Toplam } & 5.92 & 3.75 & 0.36 & 1.0 & 19.0 & & \\
\hline \multirow{3}{*}{2} & 1 & 40.93 & 15.26 & 2.88 & 14.0 & 64.0 & \multirow{4}{*}{0.349} & \multirow{4}{*}{0.706} \\
\hline & 2 & 39.07 & 13.63 & 2.49 & 10.0 & 76.0 & & \\
\hline & 3 & 37.97 & 13.00 & 2.23 & 16.0 & 60.0 & & \\
\hline \multicolumn{2}{|c|}{ Toplam } & 39.23 & 13,83 & 1.44 & 10.0 & 76.0 & & \\
\hline \multirow{3}{*}{3} & 1 & 69.70 & 17.17 & 3.84 & 48.0 & 102.0 & \multirow{4}{*}{5.262} & \multirow{4}{*}{$0.008^{*}$} \\
\hline & 2 & 56.52 & 19.19 & 3.84 & 28.0 & 110.0 & & \\
\hline & 3 & 71.48 & 15.47 & 3.23 & 48.0 & 103.0 & & \\
\hline \multicolumn{2}{|c|}{ Toplam } & 65.46 & 18.49 & 2.24 & 28.0 & 110.0 & & \\
\hline
\end{tabular}

*P<0.05: \%95 güven düzeyinde istatistiksel olarak anlamlı fark var.

Varyans analizi sonucunda diri örtü müdahalesi uygulamaları bakımından bir yaşındaki ve üç yaşındaki gençlik boyları arasında \%95 güven düzeyinde anlamlı farklılık olurken 2 yaşındaki boylarda anlamlı bir farklılık olmamıştır. Varyans analizi sonucunda istatistiksel olarak 1. ve 3. yaşındaki gençlik boylarının işlemlere bağlı olarak anlamlı farklılık gösterdiği belirlendikten sonra, gençlik boylarının nasıl bir gruplandırma içerisinde oldukları Duncan testi ile tespit edilmiş ve elde edilen sonuçlar Şekil 4'de gösterilmiştir. 2 yaşındaki gençlik boyları işlemler bakımından farklılık göstermediğinden dolayı Duncan testine tabi tutulmamıştır.

Bir yaşındaki gençliklerde yapılan ölçümlerde tüm işlemlere ait ortalama gençlik boyu $5.92 \mathrm{~cm}$ olarak belirlenmiştir. Maksimum gençlik boyu $(19 \mathrm{~cm}) 3$. işlemde elde edilirken, minimum boy değeri $(8 \mathrm{~cm}) 1$. işlemde tespit edilmiştir. İki yaşındaki boylarda yapılan ölçümlerde tüm işlemlere ait ortalama gençlik boyu $39.23 \mathrm{~cm}$ olarak belirlenmiştir. Maksimum boy değeri $76 \mathrm{~cm}$ ve minimum boy değeri $60 \mathrm{~cm}$ olarak 2. işlemde tespit edilmiştir. Üç yaşındaki boylarda yapılan ölçümlerde tüm işlemlere ait ortalama gençlik boyu $65.46 \mathrm{~cm}$ olarak belirlenmiştir. Maksimum gençlik boyu $(110 \mathrm{~cm})$ ve minimum boy değeri $(28 \mathrm{~cm})$ 2. işlemde görülmüştür.

Yapılan Duncan testi sonucunda 1 yaşındaki ve 3 yaşındaki gençliğin boyları ile işlemler arasında 2 farklı grubun meydana geldiği tespit edilmiştir. Bir yaşındaki gençliklerde; 1 . işlem ve 2 . işlem bir grupta, 3 . işlem ise tek başına grup meydana getirmiştir. Üç yaşındaki gençliklerde; 1 . işlem ve 3. İşlem aynı grupta yer alırken, 2. işlem tek başına grup oluşturmuştur. illk yıl 3.işlemin uygulandığı alandan daha boylu fidanlar elde edildiği, ilerleyen yıllarda ise bu boy farkının kapandığı görülmüştür. Böylelikle ilk yıl diri örtü temizliğin yapılmasının, sonraki yıllarda ise diri örtü temizliğine gerek olmadığı ortaya çıkmıştır. 


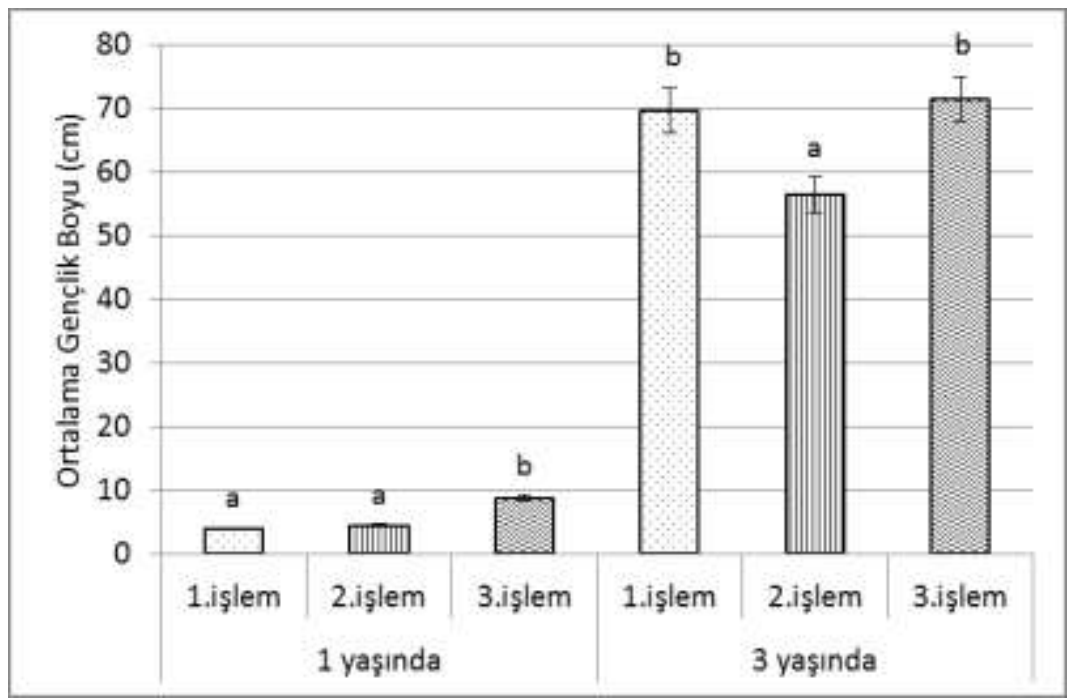

Şekil 4. Diri örtü temizliğinin bir ve üç yaşındaki gençliğin boyları ve Duncan testi sonuçlarını gösteren histogram

Diri örtü temizliği işlemlerine bağlı olarak bir ve üç yaşındaki gençlik boyları arasındaki farkların istatistiksel olarak anlamlııı̆ı Bonferroni (ikili karşılaştırma) testi ile belirlenmiş ve sonuçlar Çizelge 2 'de gösterilmiştir. 2 yaşındaki gençliklerin işlemler bakımından aralarından bir farklıık olmadığından Bonferroni testine tabi tutulmamıştır.

Çizelge 2. Diri örtü temizliğinin ortalama gençlik boyuna göre Bonferroni testi sonuçları

\begin{tabular}{|c|c|c|c|c|c|}
\hline Gençliğin Yaşı & (I) İşlemler & (J) İşlemler & $\begin{array}{c}\text { Ortalamalar Farkı } \\
\text { (I-J) }\end{array}$ & Standart Hata & Önem Düzeyi \\
\hline \multirow{6}{*}{1} & \multirow{2}{*}{1} & 2 & -0.53 & 0.74 & 1.000 \\
\hline & & 3 & $-4.86^{*}$ & 0.71 & $0.000^{*}$ \\
\hline & \multirow{2}{*}{2} & 1 & 0.53 & 0.74 & 1.000 \\
\hline & & 3 & $-4.33^{*}$ & 0.70 & $0.000^{*}$ \\
\hline & \multirow{2}{*}{3} & 1 & $4.86^{*}$ & 0.71 & $0.000^{*}$ \\
\hline & & 2 & $4.33^{*}$ & 0.70 & $0.000^{*}$ \\
\hline \multirow{6}{*}{3} & \multirow{2}{*}{1} & 2 & $13.18^{*}$ & 5.22 & $0.042^{*}$ \\
\hline & & 3 & -1.78 & 5.32 & 1.000 \\
\hline & \multirow{2}{*}{2} & 1 & $-13.18^{*}$ & 5.22 & $0.042^{*}$ \\
\hline & & 3 & $-14.96^{*}$ & 5.03 & $0.012^{*}$ \\
\hline & \multirow{2}{*}{3} & 1 & 1.78 & 5.32 & 1.000 \\
\hline & & 2 & $14.96^{*}$ & 5.03 & $0.012^{*}$ \\
\hline
\end{tabular}

*P<0.05: \%95 güven düzeyinde istatistiksel olarak anlamlı fark var

Yapılan Bonferroni testi sonucunda bir yaşındaki gençlik boylarına ilişkin olarak; 1 ve 2 nolu işlemlerin 3 . işlem ile 3. işlemin ise 1 ve 2 nolu işlemlerle arasında \%95 güven düzeyinde anlamlı farklılıkların olduğu belirlenmiştir. 1. işlem ve 2. işlem arasından 1 yıllık boy ortalamaları bakımında arasındaki fark istatistiksel olarak anlamlı ( $P>0.05$ ) bulunmamıştır. Üç yaşındaki gençlik boylarında ise; 1 . işlem ile 2 . işlemin ve 2 . işlem ile 3 . işlemlerin arasında \% 95 güven düzeyinde anlamlı farklılıkların olduğu belirlenmiştir. 3. işlemin ise 1 . işlem ile aralarında istatistiksel olarak anlamlı ( $P>0.05)$ bir fark bulunmamıştır.
Edwards (1980), gençleştirme çalışmasından sonra gençlik bakımının yapılmasının gerektiğini vurgulamaktadır. Gençlik bakımı yapılmayan alanlarda, diri örtü gençliğin normal büyümesini engellemekte, artım kayıplarına neden olmakta, yer yer de gençliği boğarak öldürmektedir (Eler ve ark. 1992). Odabaşı ve ark. (2004), yapmış oldukları çalışmalarda gençlik evresinde diri örtünün tehlike oluşturduğu alanlarda diri örtü ile mücadelenin gerekliliğini ortaya koymuşlardır. Bu çalışmayla da özellikle 1. yaşta diri örtü ile mücadele olarak uygulanan bakım müdahalesinin ne kadar yerinde olduğu ortaya koyulmuştur. Claessens ve ark. (2010)'da, 
kızılağacın doğal gençleştirme çalışmalarında açıklıklara ihtiyaç duyduğu ve toprak işlemesinin veya meşcere kapalılığının kırılmasının gençleştirmeyi etkilediği belirtilmiş. Ayrıca, çimlenme aşamasındaki ilk bir aylık dönemin çok önemli olduğunu, ışık yanında toprak rutubetinin yüksek olması gerektiği ifade edilmektedir. Mc Vean (1956), $1000 \mathrm{~m}^{2 \prime}$ lik açıklıklar dışındaki kapalı ortamlarda kızılağacın doğal olarak gençleştirilemeyeceğini, aynı zamanda doğal yayılış alanlarındaki yoğun diri örtünün de gençliklerin gelişimini olumsuz etkileyeceğini ifade etmektedir. Bu çalışma sonucunda ise aksine 3 yaş grubundaki gençliklerde 1 . işlem grubu ile 3.işlemdeki gençliklerin boy farkının anlamsız olması boy gelişiminin diri örtü baskısından etkilenmediğini göstermektedir. Pamay (1967), kızılağaçların doğal ortamda kolayca gençleşebildiğini ve meşcere siperi altında mineral toprağın açığa çıkarıldığı yerlerde gelen gençliklerin \%30 ışık entansitesinde iyi geliştiğini tespit etmiştir. Bu çalışmada göstermektedir ki, diri örtü temizliğinin gençlik sayıları ve boyları üzerine etkili olduğu sonucu literatür çalışmaları ile benzerlik göstermektedir.

\section{SONUÇ VE ÖNERILER}

Bu çalışma, 2012 yılında Tirebolu Orman İşletme Müdürlüğü Harşit Orman İşletme Şefliği sınırları içerisinde yer alan bozuk kızılağaç meşceresinde gerçekleştirilmiştir. Doğal gençleştirme çalışmasına yönelik silvikültürel müdahaleler ile elde edilen gençliklerde yapılması gerekli olan gençlik bakımı tedbirlerinden diri örtü mücadelesi ele alınmıştır. Orman amenajman planında bozuk kızılağaç olarak gösterilen bölmede 2012 sonbaharda TK yapılmış, 2013 yılında çimlenmeler tespit edilmiş ve diri örtüye yönelik müdahaleler uygulanmıştır. Gençleştirme sahasında IK'ne ihtiyaç duyulmamış, 2016 sonbaharda yapılan BK uygulanmıştır.

2013 yılında üç işlem şeklinde gerçekleştirilen diri örtü müdahalesinin arazi ve analiz sonuçları göstermiştir ki kızılağaç gençlikleri üzerinde uygulanan şiddetli bakım müdahalesi boy gelişimi ile doğru orantılı etki oluşturmaktadır. Buradan hareketle kızılağacın özellikle ilk gençlik yıllarından itibaren ışık isteği yüksek bir tür olup biyolojikmen bağımsız hale geldikten sonra üzeri mutlaka açılmalıdır.

2014 yılında uygulanan bakım çalışmalarının boylanmalar üzerinde etkili olmadığı görülmüştür. 2015 yılında ise kontrol ve diri örtünün tamamı uzaklaştırılmış işlemlerinin aynı etkiyi yarattığı gözlenmiş olup 3 yaşında gençliğin biyolojik bağımsızlığını kazandığını ve özellikle 1 . yılda gençliklere uygulanacak diri örtü ile mücadelesinin yararlı olacağını söylemek mümkündür.

Gençlik bakım tedbirlerinden diri örtü işleminin sadece boylar üzerinde değil kök boğazı çapı gelişimi üzerindeki etkilerinin de belirlenebilmesi için çap ölçümlerinin de yapılmasının yararlı olacağı, daha sonra yapılacak seyreltme bakımının da çap-boy gelişimi üzerine etkilerinin araştırılmasının yerinde olacağı çalışmalarda çapın da dikkate alınması gerektiği düşünülmektedir.

Çalışmada kızılağaç gençliklerine etki eden en yaygın diri örtü elemanının böğürtlen olduğu gözlenmiştir. Gençleştirme çalışmasının başlangıcında makineli arazi hazırlığı yapılıyorsa orman gülü sahadan köklenerek uzaklaştırıldığı için tekrar alana gelmesi 4-5 yıl zaman almakta ancak böğürtlen için bu durum söz konusu olmamaktadır. 1. yaştaki gençlikler ile besin rekabetine giren böğürtlen aynı zamanda sürgünleri ile gençlikler üzerinde ağa benzer yapılar oluşturup onları boğmaktadır. Bu etkinin ileriki yaşlarda da devam ettiği, mücadelenin 2. ve 3. yaşlarda tam alanda değil de gençlik etraflarında yapılmasının gerektiği hatta sürgün kontrolü ve boğma tehlikesinin önlenmesi boyutuna geçilmesi gerektiği düşünülmektedir.

Bu çalışmada, Alnus glutinosa subsp. barbata'nın doğal yolla gençleştirme çalışması nispeten başarılı sonuçlar vermiştir. Çalışma kapsamında yapılan işlemlerin yanında farklı yükselti, bakı ve bonitetlerde de denenmesi bu türe ait doğal yolla gençleştirme konusunda rehber olabilir.

\section{TEŞEKKÜR}

Bu makale, Nihan Yıldırım tarafından KTÜ Fen Bilimleri Enstitüsü, Orman Mühendisliği Anabilim Dalı'nda hazırlanan "Sakallı Kızılağaç (Alnus glutinosa subsp. barbata) Meşceresinin Doğal Yolla Gençleştirilmesi 
(Harşit Orman İşletme Şefliği Örneği)" adlı yüksek lisans tezinin bir bölümüdür.

\section{KAYNAKLAR}

Aksoy H (1986) Silvikültür I, Ders notu (Rota baskı), İstanbul, $99 \mathrm{~s}$ Akyüz M (1998) Kızılağacın odun özellikleri ve kullanım özellikleri. K.T.Ü Orman Fakültesi Orman Mülkiyet Sorunları Sempozyumu, Ekim, Trabzon

Anonim (2015) Ormanlarımızda yayılış gösteren asli ağaç türleri. OGM Ankara (6.Baskı)

Ata C (1995) Silvikültür tekniği. Zonguldak Karaelmas Üniversitesi, Bartın Orman Fakültesi Yayın No:4/3, Bartın, $453 \mathrm{~s}$

Ayan S, Ulu F, Gerçek V, Ölmez Z (1998) Orta ve Doğu Karadeniz'deki aluviyal ve koluviyal topraklar ile taşkın yataklarından kızılağaç plantasyonuna uygun potansiyel alanlar. OGM - K.T.Ü. Orman Fak., Doğu Karadeniz Bölgesinde Orman Mülkiyet Sorunları Sempozyumu, Bildiri Metinleri Kitabı, s. 453 - 461, 8-10 Ekim 1998, Trabzon

Batu F, Kapucu F (1995) Doğu Karadeniz Bölgesi kızılağaç meşçerelerinde bonitet endeks ve hasılat tablolarının düzenlenmesi. 1. Ulusal Karadeniz Ormancılık Kongresi, Bildiriler Kitabı, Trabzon, 349-362

Carus S (1994) Belgrad ormanında dişbudak, kızılağaç ve akçaağaç yapay meşcerelerinde büyüme özellikleri. İstanbul Üniversitesi Orman Fakültesi Dergisi, 44(1-2), 129-144

Claessens H, Osterbaan A, Savill P, Rondeux J (2010) A review of the characteristics of black alders (Alnus glutinosa (L.) Gaerthn.) and their implications for silvicultural practices. Forestry, Vol. 83, 163175

Çatalçam O (2014) Samsun - Terme Subasar ormanında kızılağaç gençleştirme Çalışmaları. Artvin Çoruh Üniversitesi Fen Bilimleri Enstitüsü Yüksek Lisans Tezi, Artvin,43 s

Edwards P N (1980) Does pre-commercial thinning have a place in plantation forestry in Britain? Schriften, Forstliche Fakultat, Universitat Gottingen/Niedersachsische Forstliche Versuchsanstalt, 67, 214-223

Eler Ü, Şenergin Ş, Örtel E (1992) Antalya yöresinde siper ve tıraşlama yöntemine göre kızılçam (Pinus brutia Ten.) gençleştirme alanlarında gençliğin yaşama durumu. Ormancılık Araştırma Enstitüsü, Teknik Bülten No 228, Ankara, 43 s
Genç M (2013) Silvikültür tekniği. SDÜ Orman Fakültesi yayın No: 46. Isparta

Güdül H, Aydın İ, Demir A (2019) Kızılağaç (Alnus glutinosa subsp. barbata (C.A. Mey.) Yalt.) kontrplaklarının bazı teknolojik özellikleri üzerine dikim aralığının etkisi. Politeknik Dergisi, 22(3): 771-777

Güner A, Aslan S, Ekim T, Vural M, Babaç MT (edlr) (2012) Türkiye bitkileri listesi (damarlı bitkiler). Nezahat Gökyiğit Botanik Bahçesi ve Flora Araştırmaları Derneği Yayını, 1290, İstanbul

Huss J, Kahveci O (2009) Türkiye'de doğaya yakın yapraklı orman İşletmeciliği. OGEM-VAK, Ankara

Kaya M (2014) Arhavi ilçesi bal ormanındaki sakallı kızılağaç (Alnus glutinosa subsp. barbata) ormanlarında gençleştirme çalışmaları. Artvin Çoruh Üniversitesi Fen Bilimleri Enstitüsü Yüksek Lisans Tezi, Artvin, $42 \mathrm{~s}$

Mamıkoğlu NG (2015) Türkiye'nin ağaçları ve çalıları. NTV Yayınları, 6. Baskı, Ankara

Mc Vean DN (1956) Ecology of Alnus glutinosa (L.) Gaertn: V. Notes on some British alder populations. The Journal of Ecology, 321-330

Odabaşı T, Çalışkan A, Bozkuş HF (2004) Silvikültür tekniği (silvikültür II). iÜ Yayın No: 4459, OF Yayın No: 475. İstanbul, $314 \mathrm{~s}$

Öztürk G (2015) Farklı aralık mesafede oluşturulmuş kızılağaç meşcerelerinde bazı odun özellikleriyle yetişme ortamı özelliklerinin araştırılması. Artvin Çoruh Üniversitesi Fen Bilimleri Enstitüsü Yüksek Lisans Tezi, Artvin, $75 \mathrm{~s}$

Pamay B (1966) Türkiye'de yaş sınıflan metodunun uygulanmasından doğal gençleştirme problemleri (silvikültürel planlama). Fakülteler Matbaası.

Pamay B (1967) Demirköy-lğneada Longos ormanlarının silvikültürel analizi ve verimli hale getirilmesi için alınması gereken silvikültürel tedbirler üzerine araştırmalar. Orman Genel Müdürlüğü Yayın No: 451/43, İstanbul

Saatçioğlu F (1946) Türkiye'de orman gençleştirme tekniği. Orman ve Av, Sayı 8

Saatçioğlu $F$ (1979) Silvikültür tekniği (silvikültür II). i..ü. Orman Fakültesi Yayınları, No:2490/268, İstanbul

Ürgenç S (1992) Ağaç ve süs bitkileri fidanlık ve yetiştirme tekniği. i.ü. Orm. Fak. Yayın No .418, ìstanbul

Wheeler CT, Hooker JE, Crowe A, Berrie AMM (1986) The improvement and utilization in forestry of nitrogen fixation by actinorhizal plants with special reference toAlnus in Scotland. Plant and Soil, 90(1-3), 393-406

Yılmaz M (1996) Artvin-Rize yöresi kızılağaç orman ekosistemlerinin gelişimi ile bazı toprak özellikleri ve fizyografik etmenler arasındaki ilişiler. KTÜ Fen Bilimleri Enstitüsü Yüksek Lisans Tezi, Trabzon,81s 